\title{
Share pledges and firm value
}

By

\section{Michelle Li*, Chelsea Liu and Tom Scott}

\section{Version 21 February 2018}

${ }^{*}$ Accounting and Finance Department, University of Auckland Private Bag 92019, Auckland 1142, New Zealand. Phone: +64 9 9237190, Email: michelle.li@auckland.ac.nz

For comments on earlier drafts of this paper, we thank participants at the 30th Australasian Finance and Banking Conference, 2017 Auckland Region Accounting Conference and an AUT brown bag seminar. 


\begin{abstract}
Share pledging occurs when investors use their shareholding as collateral to obtain personal loans. In China, the practice of share pledging has grown exponentially in recent years, with potentially significant impacts on non-pledging shareholders, especially given high agency conflicts between controlling and minority shareholders. We empirically examine the relationship between share pledges and firm value. Using a sample of pledges by major shareholders of listed Chinese firms from 2003 through 2015, we find a positive association between share pledging and firm value. This relationship is moderated by the presence of state ownership and higher ownership concentration. Overall, we provide empirical evidence on the impacts of share pledging in the Chinese capital markets, with our findings having significant implications for investors, managers, and regulators.
\end{abstract}

Keywords: Pledging, Corporate Governance, Entrenchment

JEL codes: G10, G18, G38 


\section{Introduction}

Share pledging is the practice whereby shareholders in a public firm use their shares as collateral to secure personal loans. This practice is rarely allowed in the United States (U.S.), but has become increasingly ubiquitous in China (Celarier, 2015; Schmidt and Mak, 2017). The exponential growth in both the incidence and volume of shares pledged in China has attracted substantial media and regulatory attention in recent years (Ling, 2017; Schmidt and Mak, 2017; SCMP, 2018). Since the beginning of 2016, the number of new share pledges has totalled 12,947 . As many as 1,739 out of 2,973 publicly listed companies in China have some of their shares pledged as loan collateral, accounting for $9.78 \%$ of total market capitalization of A-shares (Ling, 2017). In extreme cases, a substantial portion of a firm's shares may be pledged by major investors. For example, the largest shareholder of Yi Li Jie Neng (stock code 600277) pledged 767 million of the company's shares in 2011, which accounted for $99.81 \%$ of its ownership interest and $85.07 \%$ of the company's total shares outstanding. In February 2018, provincial regulators in China launched an intensive investigation into stock-backed borrowings by major shareholders of public firms (SCMP, 2018). Despite the growing media attention and regulatory concerns over share pledging, there is scant empirical research on the impact of this practice on firms and investors. In this paper, we address this demand for timely evidence by examining the relationship between share pledges and the market valuation of the pledged firms.

There are two competing arguments concerning the impacts of share pledging on firm value. On one hand, share pledging increases the risk exposure of non-pledging shareholders. The loan agreement between the pledging shareholder and lender typically requires the pledged shares to be maintained above a certain value. If the share price falls below that maintenance threshold, they no longer constitute sufficient collateral, triggering a "margin call". The 
pledging shareholder may be forced to sell other shares to raise funds or pledge additional shares, otherwise the lender has the right to sell the pledged shares. This creates further downwards pressure on the share price, exacerbating stock price crash risk. Additionally, controlling shareholders who have pledged their shares may engage in suboptimal risk averse behaviour to minimise downside risk to avoid decreases in the share price, to the detriment of minority shareholders and overall firm value. On the other hand, there are reasons to expect share pledging to enhance firm value through minimizing agency conflicts. The aforementioned price crash risk associated with share pledges may serve to align the interests of large shareholders with minority shareholders, by creating common incentives to avoid decreases in share price. The threat of a share price crash has a disciplining effect on large shareholders, discouraging them from engaging in expropriation (such as tunnelling). Further, pledging could signal to the market that the major shareholder is confident that the future share price will not decrease. Both positive signalling and interest-alignment are expected to enhance firm value.

We employ a sample of 19,027 firm-year observations, consisting of firms listed on the Shanghai and Shenzhen Stock Exchanges from 2003 through 2015. We observe that, on average, $34.6 \%$ of listed firms have shares pledged by their largest shareholder over the sampling period, and this rate has increased significantly from $24.9 \%$ to $52.7 \%$ in 2015 . On average, $19.2 \%$ of a firm's total share capital is pledged, which is equivalent of $61.4 \%$ of the largest shareholder's ownership interests. Furthermore, having a shareholder pledge is associated with higher contemporaneous and future Tobin's Q. However, there is some evidence that an incremental increase in the proportion of share pledged is negatively associated with Tobin's Q. We also find that firms ceasing a shareholder pledge have lower future firm value, whereas firms commencing a shareholder pledge have higher contemporaneous firm value. Last, the effects of shareholder pledges are moderated by the 
presence of the state as the largest blockholder and ownership concentration (as proxied by the relative size of the shareholding compared with other major shareholders in the sample firms).

This study contributes to existing literature in two important ways. First, our results suggest that shareholder pledges can increase shareholder value. We attribute this positive relationship to better alignment of blockholder-minority shareholder interests, and potential signalling of future firm value by major shareholders. However, amongst the subsample with existing share pledges, a greater proportion of shares pledged is negatively associated with firm value. This suggests that increased risk of exposure to share price crashes decreases the value of share pledges. Although prior literature has shown that shareholder pledges are associated with lower firm value in other institutional contexts such as the Taiwanese and Indian capital markets (Dou et al., 2017; Singh, 2017), we argue that institutional characteristics unique to the Chinese setting (e.g. opaque information environment and weak legal protection of minority shareholders) may enhance the benefits of signalling and the value of aligning blockholder and minority shareholder interests, resulting in the positive association with firm value found. Second, we highlight majority shareholder entrenchment moderates the relationship between share pledging and firm value. When the largest shareholder is the state or has highly concentrated ownership (i.e. owns greater shareholdings than the sample median), there is less benefit from shareholder pledges aligning blockholder-minority shareholder interests, as the largest shareholder still retains the ability to extract private benefits and there is a reduction in the value of signalling.

Our findings also provide important insights to investors, corporate executives, and regulators of the Chinese capital markets, by demonstrating the relationship between share pledging and firm value. Our findings inform blockholders of the risks of excessive share pledging, and offer insights to retail investors on investment selection. Finally, in light of the exponential growth of the incidence and volume of share pledges in China and increasing 
concerns over the potential impacts on capital markets, our findings provide valuable and timely empirical evidence to policymakers in assessing the potential need for regulations to reign in this practice.

The remainder of this paper is organised as follows. Section 2 discusses the institutional background and develops the hypotheses. Section 3 describes the research design, whilst Section 4 report the empirical results. Section 5 concludes.

\section{Institutional background and literature review}

\subsection{Institutional setting}

Share pledging provides clear benefits to shareholders by enabling access to finance through stock-backed borrowings, while retaining voting and cashflow rights attached to the shares. Shareholders can use the borrowed funds for personal consumption, to diversify their portfolios, or to reinvest in the firm. However, a fall in the market price of the pledged shares would decrease the value of the collateral. If the share price falls below the maintenance threshold stipulated in the loan contract, it would trigger a "margin call”, requiring the shareholder to deposit additional collateral, for example, by pledging more shares. If the shareholder is unable to meet the margin call, the lending financial institution has the right to sell the shares in the open market to recover its loss, causing the shareholder to lose ownership.

China presents a unique institutional setting for examining the effects of share pledging on firm value for three reasons. First, unlike most developed markets (such as U.S., Australia, or UK), the legal regulations in China impose relatively few restrictions on share pledging, allowing the practice to become prevalent. According to Larcker and Tayan (2010), approximately a quarter of U.S. public firms allow executives to hedge or pledge their shareholdings. In contrast, shareholders of Chinese listed companies face less restrictions on their ability to use their shareholding as collateral to obtain loans. The Chinese Guarantee Act 
(1995) explicitly allows legally transferrable shares to be used in pledges. The Property Law, which came into effect on the $1^{\text {st }}$ October 2007, reconfirms this. The 2013 amendments to The Companies Act prescribes an approval process, whereby shareholders who intend to transfer their shares to external parties seek written consent from a majority of the remaining shareholders. However, such consent is deemed to be given, unless the dissenting shareholders undertake to purchase the shares in question themselves. ${ }^{1}$ Given that minority shareholders are unlikely to have access to sufficient financing to purchase the shares from a controlling shareholder, controlling shareholders face few practical impediments to pledging their shares. As a result of the different regulatory environment, share pledging is a far more prevalent practice in the Chinese context than in developed economies. A majority of listed companies (1,739 companies out of a total of 2,973) have issued shares currently under pledges in 2017 (Ling, 2017). Chinese stock exchange listing rules require firms to make announcements when their shares are pledged by substantial shareholders (with greater than $5 \%$ shareholdings).

Second, the legal institutions in China offer relatively weak shareholder protection compared with developed economies such as the U.S. (Levine et al., 2016). In a crossinstitutional setting, La Porta et al. (1999) find that in economies where there is weak protection of shareholder rights large shareholders have less deterrents from maximising their benefit at the expense of minority shareholders. Dou et al. (2017) find a negative market reaction to announcements of insider share pledges by firms listed on the Taipei Stock Exchange. Share pledging is also found to be associated with lower firm value in India (Singh, 2017). In the specific context of the Chinese capital markets, no prior study has examined the relationship between share pledging and firm value, though Huang and Xuan (2016) find that firms with share pledges smooth earnings more than other firms. The weaker institutional shareholder protection renders minority shareholders of Chinese listed firms more susceptible to

\footnotetext{
${ }^{1}$ According to Item 78 of The Chinese Guarantee Act (1995), where the shares of a limited liability company are pledged, the relevant provisions relating to the transfer of shares under The Companies Act shall apply.
} 
exploitation by majority shareholders, making it imperative to investigate how share pledging affects firm value and the wealth of minority investors.

Third, Chinese capital markets are characterised by high concentration of ownership and state ownership (Allen et al., 2005; Hou et al., 2012), which can also affect the potential impacts of share pledging. Prior to its market reform in 2005, the Chinese capital markets operated under a split share structure, where shares were divided into tradable and non-tradable (Qi et al., 2000). Both classes entitle the holders to the same voting and cashflow rights, but the non-tradable shares, which accounted for $70 \%$ of total shares outstanding in listed firms, could not be traded freely on stock exchanges and were held by controlling shareholders, whereas the tradable shares were primarily held by domestic individual and institutional investors (Firth et al., 2010; Li et al., 2011). Since the wealth of non-tradable shareholders was insulated from share price fluctuations, this created a conflict of interest between controlling investors (holding non-tradable shares) and minority shareholders (owning tradable shares) (e.g. Sun and Tong, 2003; Jiang et al., 2010). Despite the market reform in 2005, which enabled the holders of non-tradable shares to convert their shares to tradable shares and resulted in $97 \%$ of total A-share market capitalization becoming tradable by 2007 (Li et al., 2011), ownership interests remains highly concentrated in the hands of few controlling shareholders to date (Huang, 2016). Unlike the U.S. where executive officers in typical share pledges only own a small percentage of shares outstanding, the high ownership concentration in China renders share pledging a much more momentous phenomenon. Consequently, any failure on the part of a large shareholder to meet the margin call can trigger the sale of a substantial number of shares of a company, with significant market repercussions.

For these reasons, China presents a unique institutional setting, which both motivates and provides the opportunity for the examination of the effects of share pledging by large shareholders on firm value. 


\subsection{Hypothesis development}

Building on the agency framework outlined by Jensen and Meckling (1976), a substantial body of literature has examined agency costs arising from manager-shareholder (Fama and Jensen, 1983a, b), shareholder-debtholder (Smith and Warner, 1979; Berger et al., 1997), minority shareholder-blockholder (Denis et al., 1997; Aharony et al., 2010; Jiang et al., 2010), and blockholder-blockholder conflicts (Bennedsen and Wolfenzon, 2000; Maury and Pajuste, 2005). In this study, we focus on the agency conflicts between blockholders and minority shareholders.

Johnson et al. (2000) argue that it is not uncommon for the controlling shareholders to transfer firms' resources, a practice which they term “tunnelling”, for the purpose of expropriating minority shareholders. Subsequent research has examined the various mechanisms through which controlling shareholders can extract resources from minority shareholders, for example, through related-party transactions (Berkman et al., 2010), relatedparty loan guarantee (Huang, 2016), or appointing politically connected independent directors (Wang and Lin, 2017).

Share pledging can be perceived as another means for blockholders to expropriate firm resources at the expense of minority shareholders (Chan et al., 2015). However, there are competing views as to whether pledging increases or decreases firm value. On one hand, share pledging can potentially increase firm value through two mechanisms: blockholder-minority shareholder interest alignment and signalling. A pledging shareholder faces the potential risk of losing his or her majority shareholding, in the event of a "margin call” trigged by declines in the share price. This creates significant incentives for controlling shareholders to maximise the firm's share price in order to avoid margin calls. Such incentives may have a disciplining effect on the controlling shareholders, motivating them to refrain from practices detrimental to the interests of minority shareholders, such as tunnelling and engaging in related-party 
transactions, which are otherwise common avenues of exploitation (Johnson et al., 2000; Aharony et al., 2010; Huang, 2016).

Additionally, signalling is an important avenue for disseminating information to the market and reducing information asymmetry (Spence, 2002; Connelly et al., 2011), especially in a regulatory environment with high information asymmetry and low transparency (Cheung et al., 2010; Kun-Chih et al., 2016). ${ }^{2}$ We argue that share pledging by major shareholders provides a potent signal of their private belief in the firm's future prospects. If a blockholder pledges shares as collateral to obtain financing, it indicates a favourable assessment of the firm's future valuation relative to its current valuation supported by the blockholder's private information, resulting in confidence in the future sustainability of the firm's share price.

On the other hand, share pledging is portrayed negatively in the media, with descriptions ranging from a "controversial" method of fundraising to an avenue of corporate fraud. Share pledging is also perceived to be symptomatic of shareholder entrenchment and underlying corporate governance weaknesses (e.g. Schmidt and Mak, 2017). In particular, share pledges could decrease firm value by increasing stock price crash risk. A significant decrease in the share price can trigger a margin call, requiring the pledging shareholder to deposit more assets to make up for the fall in the value of the collateral. However, the pledging shareholders may face constraints preventing them from meeting margin calls, either because they suffer a simultaneous shrinking in the value of their other assets comprising of nonpledged shares of the same firm, or due to their lack of liquid assets which has prompted them to originally pledge shares. Consequently, the margin call can result in the pledged shares being sold by either the pledger or the lender. This can in turn affect other shareholders, triggering further sales and resulting in a downward price spiral. Therefore, shareholder pledges increase stock price crash risk. Consistent with this view, Dou et al. (2017) who investigates shareholder

\footnotetext{
${ }^{2}$ For example, prior studies have documented significant positive signalling effects associated with share repurchases (e.g. Vermaelen, 1981; Louis and White, 2007).
} 
pledges by firms listed on the Taipei Stock Exchange, find a negative market reaction to announcements of shareholder pledges and that share pledges by insiders are negatively associated with firm value, which they attribute to unexpected share price declines.

Additionally, share pledges could decrease firm value by altering corporate behaviour. To avoid triggering a stock price decline, controlling shareholders may prefer risk averse behaviour to minimise the likelihood of a decline in stock price. Risk averse behaviour can create agency conflicts, from controlling shareholders protecting their private benefits of control rather than maximising minority shareholders wealth (Anderson et al., 2003; John et al., 2008). Dou et al. (2017) also document that companies with larger share pledges have less risky behaviour in terms of capital expenditure intensity and R\&D intensity. Finally, insiders could use the borrowed loans to buy additional shares in the company and derive private benefits of control or as a means to extract value from the company. In light of these competing arguments, we state our first hypothesis in the null as:

H1: There is no association between a shareholder pledge by the largest shareholder and firm value.

We expect share pledging to affect firm value, although we do not predict the direction in H1, given the competing perspectives discussed above. Furthermore, we expect blockholder entrenchment to moderate any relationship (i.e. positive or negative) between shareholder pledging and firm value. We examine two proxies of controlling shareholder entrenchment: the presence of state ownership, and highly concentrated ownership, which are both common features of the Chinese capital markets (Zhang et al., 2009; Du et al., 2014).

We posit that the presence of state ownership and concentrated blockholding serves to reduce both the benefits and risks associated with share pledging for several reasons, thereby 
weakening its impact on firm value. First, the costs of share pledges are likely to be mitigated by the presence of state or concentrated ownership. Empirical evidence suggests that stateowned enterprises receive political favours, which helps mitigate the impact of negative events such as financial fraud scandals (Yu et al., 2015). Given that politically connected firms are more likely to have access to resources and financing, in the event of a margin call (e.g. Piotroski and Zhang, 2014), state-owned firms are expected to be more capable of obtaining emergency funds to avoid a downward price spiral. Therefore, the risk of share price crash associated with pledging is reduced when the state is the largest shareholder of the firm, mitigating risks to other shareholders. Greater ownership concentration is also negatively associated with stock price crash risk in China (Gao et al., 2017), with less dispersion of shares reducing the chance of a downwards price spiral spreading through minority shareholders. Furthermore, as entrenched shareholders have a reduced risk of exit, they are less likely to alter their behaviour to be more risk averse after a shareholder pledge, reducing these agency costs for other shareholders.

On the other hand, entrenched (state and concentrated) ownership is also expected to hamper the positive implications associated with share pledging. First, both theoretical and empirical researchers argue that ownership concentration is associated with greater exploitation of minority shareholders, to the detriment of firm value (Stulz, 1988; McConnell and Servaes, 1990; Hou et al., 2012). Given that more entrenched blockholders have a greater ability to extract private benefits from minority shareholders (Hou et al., 2012), they are less likely to refrain or be hindered from such expropriating behaviours after commencing share pledges. Furthermore, as discussed above, state-owned firms and firms with concentrated ownership interests also face lower threats of stock price crashes as a result of easier access to financing and lower share dispersion. The lower risk of price crashes weakens the disciplining effect on blockholders by discouraging them from expropriating firm resources. Consequently, the 
effectiveness of shareholder pledges in aligning of blockholders and minority shareholder interests is likely reduced. Last, controlling shareholder entrenchment would also impact on the effectiveness of signalling in the context of information asymmetry. Stiglitz (2000) identifies two broad types of asymmetric information: information about quality and information about intent. In an institutional environment with high conflicts of interest between blockholders and minority shareholders, blockholders not only have superior information regarding the quality of the firms, but minority shareholders are also wary of blockholders' intent to expropriate firm resources at their expense. We therefore expect that, in firms with entrenched major shareholders, while the quality-related signal associated with pledging remains unchanged, minority shareholders are less likely to derive a positive signal relating to the intent of blockholders not to engage in expropriation.

For these reasons, we expect presence of more entrenched controlling shareholders (state ownership and high ownership concentration) to reduce both the benefit and costs of shareholder pledges. As outlined in H1, we do not predict the sign of the association between shareholder pledges and firm value, accordingly we specify our second hypotheses as:

H2a: Any association between shareholder pledging and firm value is moderated by state ownership.

H2b: Any association between shareholder pledging and firm value is moderated by greater blockholding by the largest shareholder.

\section{Research design}

\subsection{Sample selection}

Our initial sample comprised all firms listed on the Shanghai and Shenzhen Stock Exchanges between 2003 and 2015. Although CSMAR does not provide the announcement dates for shareholder pledges, it provides data on the number of shares in a firm pledged by its top 10 
shareholder. All other financial and corporate governance data is also obtained from CSMAR. After excluding firms with missing total assets, missing value for the number of board of directors and listing age of zero, the final sample consists of 19,027 firm-year observations comprising 2,503 unique listed firms.

\subsection{Regression models}

First, we examine the relationship between shareholder pledges by the largest shareholder of each firm (H1) through the following panel regression, controlling for year and firm fixed effects.

$$
\begin{aligned}
& \text { Tobins }_{i, t}=\beta_{0}+\beta_{1} \text { Pledge }_{i, t}+\beta_{2} \text { Size }_{i, t}+\beta_{3} \text { Growth }_{i, t}+\beta_{4} \text { Leverage }_{i, t}+ \\
& \beta_{5} \text { Board }_{i, t}+\beta_{6} \text { BIND }_{i, t}+\beta_{7} \text { CEODual }_{i, t}+\beta_{8}{\text { Top } 10_{i, t}}+\varepsilon_{i, t}
\end{aligned}
$$

The dependent variable, Tobin's Q, is calculated as the sum of the market value of equity and total liabilities divided by total assets. Since the effect of pledging may appear over a longer horizon, we report results using Tobin's Q both from the current $(t)$ and future period $(t+1)$. The explanatory variable of interest, Pledge, is an indicator variable that equals one if the largest shareholder of the firm in that year has made a pledge and zero otherwise. In additional analysis, we rerun the regressions using a restricted sample comprising solely of firms with a shareholder pledge, and replace the dummy variable Pledge with two different continuous variables which represent the proportion of shares pledged. Pledge_Total is computed as the average number of shares pledged by the controlling shareholder divided by the total shares outstanding in that year. Alternatively, Pledge_Largest equals the average number of shares pledged by the largest shareholder divided by the total number of shares they hold in the company. 
We employ standard control variables for firm characteristics and governance variables. Specifically, we control for Size measured as the natural logarithm of total assets; Growth measured as the percentage increase in total assets; Leverage calculated as total debt divided by total assets; Board is the number of directors on the board; BIND is the number of independent directors divided by total board size; CEODual is a binary variable equal to one if the CEO also chairs the board of directors and zero otherwise; and Top10 is the cumulative shareholding of the 10 largest shareholders. We winsorise the outlying $1 \%$ of all continuous variables.

Next, we test $\mathrm{H} 2$ by including binary variables representing state ownership (State) and large blockholders (Large), and interacting these variables with the pledging variables. State equals one if the ultimate shareholder is the central or local government, or a governmentcontrolled SOE, and zero otherwise. Large equals one if the largest shareholder's ownership interests in the firm is greater than the median ownership interests amongst the largest shareholders of all sample firms, and zero otherwise. Pursuant to H2 which hypothesizes a moderating effect of state ownership and a larger blockholder, the interaction terms (between the pledge variables and State/Large) are expected to have predicted signs opposite to the estimated coefficients on the pledge variables.

\section{Results}

\subsection{Descriptive statistics}

Table 1 provides information about the frequency of shareholder pledges. Overall, over onethird (34.6\%) of the firm-year observations have shares pledged by their largest shareholders. Share pledges becomes increasingly common over the sample period, from $24.9 \%$ in 2003 to $52.7 \%$ of the sample observations in 2015. The mean percentage of shares pledged by the largest shareholders as a proportion of total shares on issue is $19.2 \%$, although this has 
decreased over the sample period from 22.2\% in 2003 to $15.8 \%$ in 2015. The number of shares currently pledged totals a significant $61.4 \%$ of all shares held by the largest shareholders of Chinese listed firms.

Panel B shows that pledging is more common in non-state-controlled firms, where the frequency of pledging is $55.7 \%$ relative to $19.2 \%$ in state-controlled firms. Panel B also reports pledging by firm industry. Companies in stable industries with greater tangible assets to secure loans (e.g. Railways, Electricity) have the lowest rates of pledging, whilst growing industries with less tangible assets have the highest pledging (e.g. Information Technology, Health).

Panel $\mathrm{C}$ reports time series data on the changes in firm pledging status. Of the 6,577 firm-year observations that have shareholder pledges, $69.2 \%(4,554)$ were pledged in the year before. Only 8.4\% (554) of pledged observations ceased having a shareholder pledge in the following year. This suggests that there is relatively low variation in firm pledging status, especially as firms new to the sample (e.g. by listing on the stock exchanges) may have made a share pledge in a prior year.

Table 2 shows our sample firm descriptive statistics. The mean Tobin's Q is 2.469, ranging from 0.891 to 12.627 . Firm size ranges from RMB¥165 million to RMB¥ 347,000 million. Similarly, growth rates differ significantly across the sample firms, ranging from a negative rate of $40.5 \%$ to a rapid rate of expansion of $142.3 \%$. The mean ownership by the largest 10 shareholders is $55.4 \%$, and only $1.1 \%$ of firms have a CEO who is also the chair of the board.

Table 3 reports univariate $t$-tests between firms that have shares pledged by the largest shareholders and those that do not. Firms with share pledges have a higher Tobin's Q than those that do not, with a mean of 2.696 relative to 2.348 . However, we also find that pledged firms tend to be smaller, with faster growth, higher leverage, smaller boards, lower board independence, and lower ownership concentration (Top10). Firms with shareholder pledges are 
also less likely to have the state as their ultimate owner. However, we leave any formal interpretation of our results to our multivariate analysis below.

\subsection{Multivariate test of $\mathrm{H} 1$}

Table 4 presents the multivariate regression results. Although not the focus of this paper, we note that the estimated coefficients of the control variables are largely consistent with expectations, and the models are a reasonable fit with an adjusted $\mathrm{R}^{2}$ of 0.402 , which is comparable with other prior studies (e.g. Dou et al., 2017). Multicollinearity is not likely to be a major issue as the largest pairwise correlation is 0.343 between Size and BIND. Columns (1) and (2) show that a shareholder pledge by the controlling shareholder is significantly associated with higher firm value in terms of both current and future Tobin's $\mathrm{Q}(p<0.01)$. Next, we run a sub-sample analysis using only firm-year observations with a shareholder pledge, in order to examine the incremental effect of the proportion of shares pledged. We examine the proportion of pledged shares, both as a percentage of the total number of the firm's shares on issue (Pledge_Total), and as a percentage of the shares held by the largest shareholders (Pledge_Largest). We find that both are negatively and significantly associated with contemporaneous Tobin's Q only ( $p<0.10$ and $p<0.05$ ) in Columns (3) and (5), respectively. We attribute the lack of association with future Tobin's Q to the likelihood of further future changes in the proportion of shares pledged.

Overall, we find evidence to reject the null hypothesis H1, as shareholder pledges are significantly associated with firm value. However, whilst pledging firms have higher firm value compared with firms with no pledges at all (Columns (1)-(2)), as the proportion of pledged shares increases, any incremental share pledge is negatively associated with firm value. We

attribute the increase in firm value to the alignment of blockholder-minority shareholder interests, and signalling of the blockholders' faith in the sustainability of the firm's share price. 
However, as the proportion of shares pledged rises, the increase in the potential stock price crash risk decreases the alignment and signalling benefits. Our findings differ from Dou et al. (2017), who document a negative association between pledging and Tobin’s Q for firms listed on the Taipei Stock Exchange. Our results are distinguishable from those of Dou et al. (2017) due to the inherently different institutional settings. The Taipei Stock Exchange provides greater reporting guidance, which results in a lower level of opaqueness. This is likely to reduce the benefits of aligning blockholder-minority shareholder interests and signalling associated with the shares pledging in the mainland Chinese capital markets.

\subsection{Multivariate test of $\mathrm{H} 2$}

To test H2a, we rerun our main regressions analysis, by including an additional binary variable that equals one if the largest shareholder is the state. We interact this variable with our shareholder pledge variables. The results are reported in Table 5. Consistent with H2a, the estimated coefficient of the interaction term, Pledge*State, is negative and significantly associated with both contemporaneous and future firm value $(p<0.01)$ in Columns $(1)$ and $(2)$. These results indicate that the benefits associated with a share pledge is reduced when the company is state owned. This suggests that the potential benefits of share pledging, including blockholder-minority shareholder interest alignment and the signalling, are weaker within state owned companies. Next, we rerun our sub-sample analysis using only firm-year observations with share pledging in Columns (3)-(6). Consistent with the results in Table 4, the proportion of shares pledged (Pledge_Total and Pledge_Largest) remain negative and significantly associated with contemporaneous firm value in Columns (3) and (5) $(p<0.01)$, and we find some evidence that state ownership (State) moderates the relationship between the proportions of shares pledged and lower firm value, as evidenced by the significant positive estimated coefficient of the interaction term in Column (3). This indicates that the increase in risk from 
greater stock price crash risk or altered firm risk behaviour introduced by additional share pledges is weaker when the pledging shareholder is the state, compared with non-state shareholders.

In Table 6, we test H2b by including a binary variable, Large, which equals one if the largest shareholder owns a greater proportion of shares than the median shareholding amongst the largest shareholders in the sample (which is 34.0\%), and zero otherwise. We further interact this variable with our shareholder pledge variables. We also replace the variable Top10 with Top2to10, which captures the combined ownership interests of the top ten shareholders, excluding the shares owned by the largest shareholder. We find that the interaction term Pledge*Large is significantly and negatively associated with future Tobin's Q in Column (2) $(p<0.05)$, suggesting that higher ownership concentration also has a moderating effect on the benefits of pledging derived from alignment of blockholder-minority shareholder interests. These results indicate that share pledges have a greater beneficial effect on firm value by aligning blockholder and minority shareholder interests or signalling future prospects when shareholding is more disperse. Furthermore, the interaction of Large with the proportion of total shares pledged is significantly positive $(p<0.05)$, suggesting that the negative incremental effects of additional shares pledged is moderated by the pledging shareholder's high ownership concentration. Again this suggests that the costs of shareholder pledges, greater stock price crash risk and suboptimal firm behavior, are mitigated when the shareholder is more entrenched.

\subsection{Additional analysis: Changes in shareholder pledges}

Next, we provide evidence on the effect of shareholder pledges on firm value by examining changes in firms' pledge status. As outlined in Table 1 Panel C, many firms within our sample experience changes in their pledge status. In Table 7 we rerun our regressions separately by employing two sub-samples, the first consisting only of firms that had a shareholder pledge in 
the previous year and firms that remain pledged this year, as reported in Columns (1) and (2), and the second sub-sample consisting of firms that had no pledges in the previous year and firms that remain unpledged this year, as reported in Columns (3) and (4). We exclude observations with missing data from the prior year. We find that ceasing to have a shareholder pledge (StopPledge) is associated with a decrease in contemporaneous firm value, relative to firms that remain pledged. This evidence further corroborates the results from Tables 4 and 5, by indicating that pledging is associated with higher firm value. In contrast, commencing a shareholder pledge (StartPledge) is associated with an increase in firm value in the subsequent year, compared with firms that remain unpledged. Thus, apart from finding consistent evidence that shareholder pledges increase firm value, we furthermore document the asymmetric speed of reaction to changes in firms' pledging status, as ceasing a pledge is associated with an immediate decrease in firm value, whereas commencing a pledge is associated with a delayed increase in future firm value. ${ }^{3}$

\subsection{Sensitivity tests}

To ensure the robustness of results, we run a variety of robustness test. Firstly, we calculate alternative measures of Tobin's Q and find consistent results. Second, we include additional and different control variables (e.g. sales, market capitalisation, return on assets, cash holdings, the standard deviation of stock returns over the previous three years, the separation between control and cash flows rights, and the proportion of tangible assets). In untabulated results, the estimated coefficients and statistical significance of the key pledge variable (Pledge) remains unchanged, although Pledge_Total is not consistently significant. Third, we rerun the regression analysis by controlling for any combination of year, firm and industry fixed effects.

\footnotetext{
${ }^{3}$ When we examine the change in the proportion of shares pledged, we find that it is not significantly associated with a change in Tobin's Q. Thus, although changing pledge status has an effect on firm value, there does not appear to be a strong effect associated with an incremental change in the proportion of shares pledged.
} 
Our key results remain unchanged. Fourth, as discussed in Section 2.1, the share split reform in 2005 enabled shareholders to convert non-tradable shares to tradable shares, which effectively align the interests of large shareholders owning non-tradable shares and minority shareholders owning tradable shares. Accordingly, we rerun our regressions, by including a binary variable equal to one for the post-share split period, and zero otherwise. We find that the results are driven by firm-years in the post-share split reform period. However, our analysis of this issue is constrained by the relatively few number of observations with shareholder pledges in the pre-reform period.

Next, we rerun regressions based on whether the firm has lower or higher levels of debt compared with the sample median. We find that having a shareholder pledge only has a positive effect on firm value for firms with lower debt levels. As the rationale for engaging in share pledges is unknown, companies with lower debt may arguably use shareholder pledges by the largest shareholder to raise funds. However, we do not find consistent evidence when examining the proportion of shares pledged. Our analysis is constrained by the lack of public information concerning the reasons for large shareholders to pledge their shares, which constitutes a limitation of our study.

One concern in our research design is potential endogeneity arising from self-selection, as firms with certain unobserved characteristics may be more inclined to pledge shares and at the same time may have higher firm value, though there is no empirical evidence of endogeneity as our regression residuals are not significantly associated with the independent variables of interest $(p$-stat $=0.824)$. Nonetheless, we empirically address this potential issue by employing panel regressions with firm fixed effects in our main results to account for unobserved firm idiosyncrasies which may be driving firm value, as well as running a change 
analysis. The results from these analyses further suggest that our findings are not driven by endogeneity. ${ }^{4}$

\section{Conclusions}

This paper examines the effects of share pledges on firm value in the Chinese capital markets. China provides a unique research setting, characterised by both the ubiquity of share pledging, which affects a substantial proportion of market capitalisation, and the significant agency conflicts between majority and minority shareholders, which can exacerbate the impacts of share pledging on non-pledging shareholders. We show that between 2003 and 2015, 34.6\% of firms listed on the Shanghai and Shenzhen Stock Exchanges have some shares pledged by their largest shareholders. Pledged shares account for an average of $19.2 \%$ of total shares outstanding in our sample, or $61.4 \%$ of shares held by the largest shareholders. Given the conflicts between blockholder and minority shareholders, heightened by high information opaqueness and weaker institutional investor protection (La Porta et al., 2000), our examination of the valuation impacts of share pledging in the Chinese context is warranted.

This study contributes to the literature in two important ways. First, it documents novel evidence on the non-linear relationship between share pledging and firm value. Specially, our findings show that share pledging is associated with higher Tobin’s Q relative to firms whose shares are not pledged. However, we find some evidence that the incremental increase in the proportion of shares pledged is negatively associated with firm value. These results provide important insights to managers, investors, and policymakers concerning the impacts of share pledging. We attribute the increase in firm value to the alignment of blockholder-minority shareholder interests and positive signalling of future share price sustainability. However, as

\footnotetext{
${ }^{4}$ Shipman et al. (2017) highlight that propensity score matching does not address endogeneity concerns. Since the nature of the potential endogeneity is unknown, we cannot identify a valid instrumental variable that is uncorrelated with such unobserved idiosyncrasies. In these circumstances, a Heckman correction model would introduce more undue uncertainty into our results (Lennox et al., 2012).
} 
pledged shares reach a certain threshold, the increased risk exposure to share price crashes outweigh the benefits, resulting in a negative relationship between incremental increases of pledged shares and firm value.

Second, we find that the entrenchment of major shareholders, as proxied by state ownership and high ownership concentration, moderates both the up- and downside impacts of share pledges. This suggests that when a high level of shareholder entrenchment is present, the effectiveness of pledging in aligning controlling-majority shareholder interests and signalling private information about firm value is reduced, but the risks of stock price crashes and the consequent value-decreasing risk-averse behaviour of management are also mitigated.

In light of the growing prevalence of the practice of share pledging and increasing concerns expressed in the media and by regulators, this paper provides timely evidence on the valuation implications of pledging in the emerging capital markets of China. Apart from informing managers and investors as to the optimal practices of share pledging to maximise firm value, our findings have significant policy implications concerning the regulations of share pledging by major shareholders.

Nonetheless the study has two main limitations. First, whilst we observe a significant association between share pledging and firm value, we do not explore whether the incremental negative association between the proportion of shares pledged and firm value is a manifestation of tunnelling by controlling shareholders. Specifically, we are limited by the lack of information on the purpose of the pledging and the use of the loans obtained, which is not disclosed by the sample firms. Second, this paper does not examine the mechanisms through which pledging is associated with firm valuation. Given the magnitude of share pledges in the Chinese capital markets, these questions provide avenues of future research. 


\section{References}

Aharony, J., Wang, J., Yuan, H., 2010. Tunneling as an incentive for earnings management during the IPO process in China. Journal of Accounting and Public Policy 29, 1-26.

Allen, F., Qian, J., Qian, M., 2005. Law, finance, and economic growth in China. Journal of Financial Economics 77, 57-116.

Anderson, R.C., Mansi, S.A., Reeb, D.M., 2003. Founding family ownership and the agency cost of debt. Journal of Financial Economics 68, 263-285.

Asija, A., Marisetty, V.B., Rangan, S., 2014. Do insiders who pledge their shares manipulate reported earnings?

Bennedsen, M., Wolfenzon, D., 2000. The balance of power in closely held corporations. Journal of Financial Economics 58, 113-139.

Berger, P.G., Ofek, E., Yermack, D.L., 1997. Managerial entrenchment and capital structure decisions. Journal of Finance 52, 1411-1438.

Berkman, H., Cole, R.A., Fu, L.J., 2010. Political connections and minority-shareholder protection: Evidence from securities-market regulation in China. Journal of Financial and Quantitative Analysis 45, 1391-1417.

Celarier, M., 2015. Valeant CEO forced to sell shares to repay $\$ 100 \mathrm{~m}$ loan, New York Post. 15 November 2016.

Chan, K., Chen, H.-K., Hu, S.-y., Liu, Y.-J., 2015. Share pledges and margin call pressure. Working Paper.

Cheung, Y.-L., Jiang, P., Tan, W., 2010. A transparency disclosure index measuring disclosures: Chinese listed companies. Journal of Accounting and Public Policy 29, 259-280.

Claessens, S., Feijen, E., Laeven, L., 2008. Political connections and preferential access to finance: The role of campaign contributions. Journal of Financial Economics 88, 554580.

Connelly, B., Certo, T., Ireland, D., Reutzel, C., 2011. Signaling theory: A review and assessment. Journal of Management 37, 39-67.

Denis, D.J., Denis, D.K., Sarin, A., 1997. Agency problems, equity ownership, and corporate diversification. The Journal of Finance 52, 135-160.

Dou, Y., Masulis, R.W., Zein, J., 2017. Shareholder wealth consequence of insider pledging of company stock as collateral for personal loans. Working Paper, University of New South Wales.

Du, X., Jian, W., Du, Y., Feng, W., Zeng, Q., 2014. Religion, the nature of ultimate owner, and corporate philanthropic giving: Evidence from China. Journal of Business Ethics 123, 235-256.

Duchin, R., Sosyura, D., 2012. The politics of government investment. Journal of Financial Economics 106, 24-48.

Fama, E.F., Jensen, M.C., 1983a. Agency problems and residual claims. Journal of Law and Economics 26, 327-356.

Fama, E.F., Jensen, M.C., 1983b. Separation of ownership and control. Journal of Law and Economics 26, 301-325.

Firth, M., Lin, C., Zou, H., 2010. Friend or foe? The role of state and mutual fund ownership in the split share structure reform in China.

Gao, W., Li, Q., Drougas, A., 2017. Ownership structure and stock price crash risk: Evidence from china. Journal of Applied Business and Economics 19, 65-78.

Hou, W., Kuo, J.-M., Lee, E., 2012. The impact of state ownership on share price informativeness: The case of the split share structure reform in China. The British Accounting Review 44, 248-261. 
Huang, W., 2016. Tunneling through related-party loan guarantees: Evidence from a quasiexperiment in China. Review of Quantitative Finance and Accounting 47, 857-884.

Huang, Z., Xue, Q., 2016. Re-examination of the effect of ownership structure on financial reporting: Evidence from share pledges in China. China Journal of Accounting Research 9, 137-152.

Jensen, M.C., Meckling, W.H., 1976. Theory of the firm: Managerial behavior, agency costs and ownership structure. Journal of Financial Economics 3, 305-360.

Jiang, G., Lee, C.M., Yue, H., 2010. Tunneling through intercorporate loans: The China experience. Journal of Financial Economics 98, 1-20.

John, K., Litov, L., Yeung, B., 2008. Corporate governance and risk-taking. The Journal of Finance 63, 1679-1728.

Johnson, S., La Porta, R., Lopez-de-Silanes, F., Shleifer, A., 2000. Tunneling. The American Economics Review 90.

Kun-Chih, C., Qiang, C., Ying Chou, L., Yu-Chen, L., Xing, X., 2016. Financial reporting quality of Chinese reverse merger firms: The reverse merger effect or the weak country effect? The Accounting Review 91, 1363-1390.

La Porta, R., Lopez-de-Silanes, F., Shleifer, A., 1999. Corporate ownership around the world. The Journal of Finance 54, 471-517.

La Porta, R., Lopez-de-Silanes, F., Shleifer, A., Vishny, R.W., 2000. Agency problems and dividend policies around the world. The Journal of Finance 55, 1-33.

Larcker, D.F., Tayan, B., 2010. Pledge (and hedge) allegiance to the company. Rock Center for Corporate Governance at Stanford University Closer Look Series: Topics, Issues and Controversies in Corporate Governance No.CGRP-11.

Lennox, C.S., Francis, J.R., Wang, Z., 2012. Selection models in accounting research. The Accounting Review 87, 589-616.

Levine, R., Lin, C., Xie, W., 2016. Spare tire? Stock markets, banking crises, and economic recoveries. Journal of Financial Economics 120, 81-101.

Li, K., Wang, T., Cheung, Y.-L., Jiang, P., 2011. Privatization and risk sharing: Evidence from the split share structure reform in China. Review of Financial Studies, hhr025.

Ling, Q., 2017. Pledged A-shares reach \$RMB 5,800 billion, amounting to 9.78\% of total market capitalization, IFeng Financem. 12 April 2017. http://finance.ifeng.com/a/20170412/15296875_0.shtml (accessed 1 May 2017).

Louis, H., White, H., 2007. Do managers intentionally use repurchase tender offers to signal private information? Evidence from firm financial reporting behavior. Journal of Financial Economics 85, 205-233.

Maury, B., Pajuste, A., 2005. Multiple large shareholders and firm value. Journal of Banking \& Finance 29, 1813-1834.

McConnell, J.J., Servaes, H., 1990. Additional evidence on equity ownership and corporate value. Journal of Financial Economics 27, 595-612

Piotroski, J. D., \& Zhang, T., 2014. Politicians and the IPO decision: The impact of impending political promotions on IPO activity in China. Journal of Financial Economics 111, 111-136.

Qi, D., Wu, W., Zhang, H., 2000. Shareholding structure and corporate performance of partially privatized firms: Evidence from listed Chinese companies. Pacific-Basin Finance Journal 8, 587-610.

Schmidt, B., Mak, P.Y., 2017. Behind China's boldest dealmaker, billions in pledged shares, Bloomberg. 13 July 2017. https://www.bloomberg.com/news/articles/2017-0712/behind-china-s-boldest-dealmaker-billions-in-pledged-shares (accessed 15 July 2017). 
SCMP, 2018. Chinese watchdogs investigate share-backed loans to tamp down risk. South China Morning Post. 10 Feburary 2018.

http://www.scmp.com/news/china/economy/article/2132835/chinese-watchdogsinvestigate-share-backed-loans-tamp-down-risk (accessed 12 Februar 2018).

Shipman, J.E., Swanquist, Q.T., Whited, R.L., 2017. Propensity score matching in accounting research. The Accounting Review 92, 213-244.

Singh, P., 2017. Does pledging of shares by controlling shareholders always destroy firm value? Working Paper, University of Illinois: Urbana-Champaign.

Smith, C.W., Jr, Warner, J.B., 1979. On financial contracting: An analysis of bond covenants. Journal of Financial Economics 7, 117-161.

Spence, M., 2002. Signaling in retrospect and the informational structure of markets. American Economic Review 92, 434-459.

Stiglitz, J.E., 2000. The contributions of the economics of information to twentieth century economics. The Quarterly Journal of Economics 115, 1441-1478.

Stulz, R.M., 1988. Managerial control of voting rights: Financing policies and the market for corporate control. Journal of Financial Economics 20, 25-54.

Sun, Q., Tong, W.H., 2003. China share issue privatization: The extent of its success. Journal of financial economics 70, 183-222.

Vermaelen, T., 1981. Common stock repurchases and market signalling: An empirical study. Journal of Financial Economics 9, 139-183.

Wang, L., Lin, P.T., 2017. Who benefits from political connections? Minority investors or controlling shareholders. Asia-Pacific Journal of Accounting \& Economics 24, 1-22.

Yu, X., Zhang, P., Zheng, Y., 2015. Corporate governance, political connections, and intraindustry effects: Evidence from corporate scandals in china. Financial Management 44, 49-80.

Zhang, R., Rezaee, Z., Zhu, J., 2009. Corporate philanthropic disaster response and ownership type: Evidence from Chinese firms' response to the Sichuan earthquake. Journal of Business Ethics 91, 51-63. 
Table 1: Summary statistics

Panel A: Summary statistics

\begin{tabular}{l|rrrr|rr}
\hline Year & \multicolumn{2}{|c}{ Pledge } & \multicolumn{1}{c|}{ No } & Total & Pledge_Total & Pledge_Largest \\
\hline 2003 & $\mathrm{~N}$ & \multicolumn{1}{c}{ Pledge } & & & \\
2004 & 238 & 24.9 & 719 & 957 & 22.2 & 61.0 \\
2005 & 279 & 26.9 & 757 & 1036 & 22.9 & 63.7 \\
2006 & 328 & 29.3 & 791 & 1119 & 22.9 & 63.7 \\
2007 & 330 & 28.3 & 837 & 1167 & 21.3 & 66.9 \\
2008 & 318 & 26.4 & 885 & 1203 & 19.2 & 60.3 \\
2009 & 338 & 27.1 & 909 & 1247 & 19.9 & 61.7 \\
2010 & 365 & 27.1 & 981 & 1346 & 20.7 & 65.3 \\
2011 & 401 & 27.8 & 1039 & 1440 & 19.3 & 62.9 \\
2012 & 434 & 28.6 & 1082 & 1516 & 19.3 & 63.1 \\
2013 & 605 & 36.3 & 1061 & 1666 & 20.0 & 65.0 \\
2014 & 801 & 40.6 & 1170 & 1971 & 19.1 & 61.6 \\
2015 & 967 & 45.3 & 1168 & 2135 & 18.3 & 59.7 \\
Total & 1173 & 52.7 & 1051 & 2224 & 15.8 & 55.9 \\
\hline
\end{tabular}

Panel B: Pledging by firm type

\begin{tabular}{|c|c|c|c|c|c|c|}
\hline \multirow{2}{*}{ Ownership type } & \multicolumn{2}{|c|}{ Pledge } & \multirow{2}{*}{$\begin{array}{c}\text { No } \\
\text { Pledge }\end{array}$} & \multirow{2}{*}{ Total } & \multirow{2}{*}{$\begin{array}{l}\text { Pledge_ } \\
\text { Total }\end{array}$} & \multirow{2}{*}{$\begin{array}{l}\text { Pledge_ } \\
\text { Largest }\end{array}$} \\
\hline & $\mathrm{N}$ & $\%$ & & & & \\
\hline Non-State & 4467 & 55.7 & 3555 & 8,022 & 20.6 & 68.9 \\
\hline State & 2110 & 19.2 & 8895 & 11,005 & 16.2 & 45.4 \\
\hline Total & 6577 & 34.6 & 12450 & 19027 & 19.2 & 61.4 \\
\hline \multicolumn{7}{|l|}{ Industry } \\
\hline Accommodation & 38 & 34.2 & 73 & 111 & 19.0 & 79.4 \\
\hline Agriculture & 117 & 37.9 & 192 & 309 & 18.0 & 67.5 \\
\hline Construction Supply & 141 & 29.3 & 341 & 482 & 21.2 & 63.9 \\
\hline $\begin{array}{l}\text { Culture, sports and } \\
\text { entertainment }\end{array}$ & 77 & 28.0 & 198 & 275 & 20.8 & 71.4 \\
\hline Diversified & 88 & 31.0 & 196 & 284 & 15.0 & 70.1 \\
\hline Financial industry & 106 & 27.6 & 278 & 384 & 18.0 & 65.9 \\
\hline Health and social work & 25 & 55.6 & 20 & 45 & 24.8 & 69.7 \\
\hline Industry Electric power & 221 & 22.9 & 743 & 964 & 18.0 & 54.1 \\
\hline Information Technology & 334 & 44.4 & 419 & 753 & 16.2 & 63.2 \\
\hline $\begin{array}{l}\text { Leasing and Commercial } \\
\text { service }\end{array}$ & 96 & 38.3 & 155 & 251 & 20.4 & 61.7 \\
\hline Manufacturing & 3888 & 36.5 & 6766 & 10654 & 18.4 & 58.1 \\
\hline Mining & 240 & 39.3 & 370 & 610 & 21.6 & 62.3 \\
\hline Railway & 91 & 12.1 & 663 & 754 & 20.6 & 62.3 \\
\hline Real estate & 599 & 42.8 & 802 & 1,401 & 24.6 & 69.2 \\
\hline Scientific research & 21 & 22.6 & 72 & 93 & 13.7 & 58.5 \\
\hline Water conservancy & 81 & 36.5 & 141 & 222 & 19.0 & 67.2 \\
\hline Wholesale and retail & 414 & 28.9 & 1021 & 1435 & 21.0 & 69.2 \\
\hline Total & 6577 & 34.6 & 12450 & 19027 & 19.2 & 61.4 \\
\hline
\end{tabular}


Panel C: Changes in pledge status

\begin{tabular}{|c|c|c|c|c|c|c|c|c|}
\hline \multirow{2}{*}{ Year } & \multirow{2}{*}{ Pledge } & \multirow[b]{2}{*}{ Stay Pledged } & \multirow{2}{*}{$\begin{array}{l}\text { No pledge } \\
\text { to pledge }\end{array}$} & \multirow{2}{*}{$\begin{array}{l}\text { Pledge to no } \\
\text { pledge }\end{array}$} & \multirow{2}{*}{ Remain unpledged } & \multicolumn{3}{|c|}{ New firms included } \\
\hline & & & & & & Pledge & No pledge & Total \\
\hline 2003 & 238 & & & & & & & \\
\hline 2004 & 279 & 191 & 65 & 38 & 641 & 23 & 78 & 101 \\
\hline 2005 & 328 & 240 & 68 & 29 & 665 & 20 & 97 & 117 \\
\hline 2006 & 330 & 249 & 66 & 57 & 690 & 15 & 90 & 105 \\
\hline 2007 & 318 & 238 & 59 & 57 & 718 & 21 & 110 & 131 \\
\hline 2008 & 338 & 250 & 59 & 54 & 793 & 29 & 62 & 91 \\
\hline 2009 & 365 & 276 & 63 & 55 & 823 & 26 & 103 & 129 \\
\hline 2010 & 401 & 305 & 73 & 48 & 874 & 23 & 117 & 140 \\
\hline 2011 & 434 & 340 & 72 & 48 & 942 & 22 & 92 & 114 \\
\hline 2012 & 605 & 400 & 146 & 26 & 918 & 59 & 117 & 176 \\
\hline 2013 & 801 & 538 & 84 & 45 & 945 & 179 & 180 & 359 \\
\hline 2014 & 967 & 682 & 118 & 54 & 989 & 167 & 125 & 292 \\
\hline 2015 & 1173 & 845 & 163 & 43 & 915 & 165 & 93 & 258 \\
\hline Total & 6577 & 4554 & 1036 & 554 & 9913 & 749 & 1264 & 2013 \\
\hline
\end{tabular}

Table 1 sample summary statistics about share pledges sample. Panel A reports the frequency of share pledges and mean proportion of shares pledge by the largest shareholder for publicly listed companies between 2003 and 2015. Panel B reports the share pledge statistics by whether the largest shareholder is the State and by industry breakdown where the industry classification is provided by the CSRC 2012 Guidelines. Panel C reports changes in firms share pledge status over time. 
Table 2: Sample descriptive statistics

\begin{tabular}{lrrrrrr}
\hline & Mean & Std. Dev. & \multicolumn{1}{c}{ Median } & \multicolumn{1}{c}{ Min. } & \multicolumn{1}{c}{ Max. } & \multicolumn{1}{c}{ N } \\
\hline Pledge & 0.346 & 0.476 & 0 & 0 & 1 & 19027 \\
Pledge_Total & 19.214 & 11.806 & 17.300 & 1.200 & 55.877 & 6577 \\
Pledge_Largest & 61.383 & 29.832 & 57.503 & 4.423 & 100.000 & 6577 \\
TobinsQ & 2.469 & 1.953 & 1.819 & 0.891 & 12.627 & 19027 \\
TA (RMB, mil) & 11,100 & 38,600 & 2,670 & 165 & 347,000 & 19027 \\
Size & 21.853 & 1.334 & 21.705 & 18.924 & 26.573 & 19027 \\
Growth & 0.136 & 0.262 & 0.087 & -0.405 & 1.423 & 19027 \\
Leverage & 0.511 & 0.233 & 0.508 & 0.053 & 1.513 & 19027 \\
Board & 9.149 & 2.003 & 9 & 3 & 22 & 19027 \\
BIND & 0.363 & 0.054 & 0.333 & 0.071 & 0.800 & 19027 \\
CEODual & 0.013 & 0.114 & 0 & 0 & 1 & 19027 \\
Top10 & 55.402 & 15.339 & 56.030 & 20.840 & 90.280 & 19027 \\
\hline Tap & 5.450
\end{tabular}

Table 2 reports sample descriptive statistics. Where; Pledge is an indicator variable that equals one if the largest shareholder of the firm in that year has made a pledge and zero otherwise; Pledge_Total is the average number of shares pledged by the controlling shareholder divided by the total shares outstanding in that year; Pledge_Largest is the average number of shares pledged by the largest shareholder divided by the total number of shares they hold in the company; Size is the natural logarithm of total assets; Growth is the percentage increase in total assets; Leverage is total debt divided by total assets; Board is the number of directors on the board; BIND is the number of independent directors divided by total board size; CEODual is a binary variable that equals to one if the CEO also chairs the board of directors and zero otherwise and Top10 is the cumulative shareholding of the 10 largest shareholders. 
Table 3: Univariate analysis

\begin{tabular}{|c|c|c|c|c|c|c|}
\hline & \multicolumn{2}{|c|}{ No Pledge } & \multicolumn{2}{|c|}{ Pledge } & \multirow[b]{2}{*}{$t$-stat } & \\
\hline & $\mathrm{N}$ & Mean & $\mathrm{N}$ & Mean & & \\
\hline TobinsQ & 12450 & 2.348 & 6577 & 2.696 & -11.745 & $* * *$ \\
\hline Size & 12450 & 21.926 & 6577 & 21.713 & 10.533 & $* * *$ \\
\hline Growth & 12450 & 0.126 & 6577 & 0.155 & -7.214 & $* * *$ \\
\hline Leverage & 12450 & 0.507 & 6577 & 0.520 & -3.811 & $* * *$ \\
\hline Board & 12450 & 9.362 & 6577 & 8.744 & 20.459 & $* * *$ \\
\hline$B I N D$ & 12450 & 0.360 & 6577 & 0.368 & -9.402 & $* * *$ \\
\hline CEODual & 12450 & 0.012 & 6577 & 0.015 & -1.381 & \\
\hline Top10 & 12450 & 56.460 & 6577 & 53.400 & 13.143 & $* * *$ \\
\hline State & 12450 & 0.714 & 6577 & 0.321 & 56.509 & $* * *$ \\
\hline
\end{tabular}

Table 3 reports univariate $t$-tests on the differences between firms that do and do not have a share pledge. Twotailed test of significance: $* * *<0.01, * *<0.05$ and $*<0.1$. 
Table 4: Pledging and firm value

\begin{tabular}{|c|c|c|c|c|c|c|}
\hline & $\begin{array}{c}(1) \\
\text { TobinsQ(t) }\end{array}$ & $\begin{array}{c}(2) \\
\text { TobinsQ }(t+1) \\
\end{array}$ & $\begin{array}{c}(3) \\
\text { TobinsQ(t) }\end{array}$ & $\begin{array}{c}(4) \\
\text { TobinsQ }(t+1) \\
\end{array}$ & $\begin{array}{c}(5) \\
\text { TobinsQ(t) }\end{array}$ & $\begin{array}{c}(6) \\
\text { TobinsQ(t+1) } \\
\end{array}$ \\
\hline Pledge & $\begin{array}{l}0.150^{* * *} \\
(0.040)\end{array}$ & $\begin{array}{l}0.155^{* * *} \\
(0.039)\end{array}$ & & & & \\
\hline Pledge_Total & & & $\begin{array}{l}-0.005^{*} \\
(0.003)\end{array}$ & $\begin{array}{l}-0.001 \\
(0.003)\end{array}$ & & \\
\hline Pledge_Largest & & & & & $\begin{array}{l}-0.003^{* *} \\
(0.001)\end{array}$ & $\begin{array}{l}-0.001 \\
(0.001)\end{array}$ \\
\hline Size & $\begin{array}{c}-1.413^{* * *} \\
(0.056)\end{array}$ & $\begin{array}{c}-1.271^{* * *} \\
(0.053)\end{array}$ & $\begin{array}{c}-1.472^{* * *} \\
(0.089)\end{array}$ & $\begin{array}{c}-1.372^{* * *} \\
(0.101)\end{array}$ & $\begin{array}{c}-1.478^{* * *} \\
(0.089)\end{array}$ & $\begin{array}{c}-1.374^{* * *} \\
(0.102)\end{array}$ \\
\hline Growth & $\begin{array}{l}0.544^{* * *} \\
(0.053)\end{array}$ & $\begin{array}{l}0.276^{* * *} \\
(0.054)\end{array}$ & $\begin{array}{l}0.479^{* * *} \\
(0.094)\end{array}$ & $\begin{array}{l}0.377^{* * *} \\
(0.106)\end{array}$ & $\begin{array}{l}0.491^{* * *} \\
(0.093)\end{array}$ & $\begin{array}{l}0.380^{* * *} \\
(0.106)\end{array}$ \\
\hline Leverage & $\begin{array}{l}0.718^{* * *} \\
(0.172)\end{array}$ & $\begin{array}{l}0.890^{* * *} \\
(0.189)\end{array}$ & $\begin{array}{l}0.475^{* *} \\
(0.219)\end{array}$ & $\begin{array}{l}0.632^{* *} \\
(0.283)\end{array}$ & $\begin{array}{l}0.484^{* *} \\
(0.217)\end{array}$ & $\begin{array}{l}0.631^{* *} \\
(0.284)\end{array}$ \\
\hline BOARD & $\begin{array}{l}-0.006 \\
(0.017)\end{array}$ & $\begin{array}{c}0.002 \\
(0.018)\end{array}$ & $\begin{array}{c}-0.102^{* * *} \\
(0.033)\end{array}$ & $\begin{array}{l}-0.042 \\
(0.038)\end{array}$ & $\begin{array}{c}-0.100^{* * *} \\
(0.033)\end{array}$ & $\begin{array}{l}-0.042 \\
(0.038)\end{array}$ \\
\hline BIND & $\begin{array}{l}0.090^{* *} \\
(0.039)\end{array}$ & $\begin{array}{c}0.028 \\
(0.043)\end{array}$ & $\begin{array}{l}0.193^{* * *} \\
(0.059)\end{array}$ & $\begin{array}{c}0.036 \\
(0.080)\end{array}$ & $\begin{array}{l}0.195^{* * *} \\
(0.059)\end{array}$ & $\begin{array}{c}0.036 \\
(0.080)\end{array}$ \\
\hline CEODual & $\begin{array}{c}0.351^{*} \\
(0.187)\end{array}$ & $\begin{array}{l}-0.003 \\
(0.172)\end{array}$ & $\begin{array}{c}0.128 \\
(0.303)\end{array}$ & $\begin{array}{l}-0.416 \\
(0.508)\end{array}$ & $\begin{array}{c}0.123 \\
(0.297)\end{array}$ & $\begin{array}{l}-0.419 \\
(0.507)\end{array}$ \\
\hline Top10 & $\begin{array}{l}0.019^{* * *} \\
(0.002)\end{array}$ & $\begin{array}{l}0.013^{* * *} \\
(0.002)\end{array}$ & $\begin{array}{l}0.024^{* * *} \\
(0.003)\end{array}$ & $\begin{array}{l}0.012^{* * *} \\
(0.004)\end{array}$ & $\begin{array}{l}0.022^{* * *} \\
(0.003)\end{array}$ & $\begin{array}{c}0.012^{* * *} \\
(0.004)\end{array}$ \\
\hline Constant & $\begin{array}{c}29.970^{* * *} \\
(1.119)\end{array}$ & $\begin{array}{c}27.111^{* * *} \\
(1.047)\end{array}$ & $\begin{array}{c}31.372^{* * *} \\
(1.787)\end{array}$ & $\begin{array}{c}29.615^{* * *} \\
(2.019)\end{array}$ & $\begin{array}{c}31.616^{* * * *} \\
(1.793)\end{array}$ & $\begin{array}{c}29.673^{* * *} \\
(2.030)\end{array}$ \\
\hline $\begin{array}{l}\text { Year/Firm F.E } \\
\text { F-Stat } \\
\text { Adj. } R^{2} \\
N \\
\end{array}$ & $\begin{array}{c}\text { Yes } \\
178.194 \\
0.420 \\
19027 \\
\end{array}$ & $\begin{array}{c}\text { Yes } \\
151.795 \\
0.381 \\
16135 \\
\end{array}$ & $\begin{array}{c}\text { Yes } \\
70.930 \\
0.452 \\
6577 \\
\end{array}$ & $\begin{array}{c}\text { Yes } \\
57.572 \\
0.393 \\
5128 \\
\end{array}$ & $\begin{array}{c}\text { Yes } \\
71.977 \\
0.452 \\
6577\end{array}$ & $\begin{array}{c}\text { Yes } \\
57.091 \\
0.393 \\
5128 \\
\end{array}$ \\
\hline
\end{tabular}

Table 4 reports ordinary least square regressions examining the effect of share pledges on both current $(t)$ and future $(t)$ Tobin's Q. Columns (1) and (2) present the results when the variable of interest, Pledge, is an indicator variable that equals one if the largest shareholder of the firm in that year has made a pledge and zero otherwise. Columns (3) and (4) present the results when the variable of interest, Pledge_Total, is the average number of shares pledged by the controlling shareholder divided by the total shares outstanding in that year. Last, Columns (5) and (6) present the results when the variable of interest, Pledge_Largest, is the average number of shares pledged by the largest shareholder divided by the total number of shares they hold in the company. All other variables are as defined earlier. Two-tailed test of significance: $* * *<0.01$, $* *<0.05$ and $*<0.1$. 
Table 5: Pledging and state ownership

\begin{tabular}{|c|c|c|c|c|c|c|}
\hline & $\begin{array}{c}(1) \\
\text { Tobins } Q(t)\end{array}$ & $\begin{array}{c}(2) \\
\text { TobinsQ }(t+1)\end{array}$ & $\begin{array}{c}(3) \\
\text { Tobins } Q(t)\end{array}$ & $\begin{array}{c}(4) \\
\text { Tobins }(t+1)\end{array}$ & $\begin{array}{c}(5) \\
\text { Tobins } Q(t)\end{array}$ & $\begin{array}{c}(6) \\
\text { TobinsQ }(t+1)\end{array}$ \\
\hline Pledge & $\begin{array}{c}0.264^{* * *} \\
(0.061)\end{array}$ & $\begin{array}{l}0.301^{* * *} \\
(0.059)\end{array}$ & & & & \\
\hline Pledge*State & $\begin{array}{c}-0.253^{* * *} \\
(0.073)\end{array}$ & $\begin{array}{c}-0.295^{* * * *} \\
(0.075)\end{array}$ & & & & \\
\hline Pledge_Total & & & $\begin{array}{c}-0.010^{* * *} \\
(0.004)\end{array}$ & $\begin{array}{c}-0.004 \\
(0.004)\end{array}$ & & \\
\hline Pledge_Total*State & & & $\begin{array}{l}0.020^{* * * *} \\
(0.007)\end{array}$ & $\begin{array}{c}0.011 \\
(0.007)\end{array}$ & & \\
\hline Pledge_Largest & & & & & $\begin{array}{c}-0.004^{* * * *} \\
(0.001)\end{array}$ & $\begin{array}{l}-0.000 \\
(0.002)\end{array}$ \\
\hline Pledge_Largest*State & & & & & $\begin{array}{c}0.003 \\
(0.003)\end{array}$ & $\begin{array}{c}-0.001 \\
(0.003)\end{array}$ \\
\hline State & $\begin{array}{c}-0.052 \\
(0.104)\end{array}$ & $\begin{array}{c}0.021 \\
(0.106)\end{array}$ & $\begin{array}{c}-0.703^{* * *} \\
(0.211)\end{array}$ & $\begin{array}{l}-0.354^{*} \\
(0.201)\end{array}$ & $\begin{array}{c}-0.518^{* *} \\
(0.237)\end{array}$ & $\begin{array}{l}-0.075 \\
(0.231)\end{array}$ \\
\hline Size & $\begin{array}{c}-1.410^{* * *} \\
(0.056)\end{array}$ & $\begin{array}{c}-1.271^{* * *} \\
(0.053)\end{array}$ & $\begin{array}{c}-1.459^{* * *} \\
(0.088)\end{array}$ & $\begin{array}{c}-1.364^{* * *} \\
(0.101)\end{array}$ & $\begin{array}{c}-1.472^{* * *} \\
(0.088)\end{array}$ & $\begin{array}{c}-1.372^{* * * *} \\
(0.101)\end{array}$ \\
\hline Growth & $\begin{array}{l}0.531^{* * * *} \\
(0.053)\end{array}$ & $\begin{array}{l}0.267^{* * * *} \\
(0.054)\end{array}$ & $\begin{array}{l}0.461^{* * * *} \\
(0.093)\end{array}$ & $\begin{array}{l}0.370^{* * * *} \\
(0.105)\end{array}$ & $\begin{array}{l}0.481^{* * * *} \\
(0.092)\end{array}$ & $\begin{array}{c}0.373^{* * *} \\
(0.104)\end{array}$ \\
\hline Leverage & $\begin{array}{c}0.730^{* * *} \\
(0.171)\end{array}$ & $\begin{array}{l}0.905^{* * *} \\
(0.189)\end{array}$ & $\begin{array}{l}0.469^{* *} \\
(0.216)\end{array}$ & $\begin{array}{l}0.635^{* *} \\
(0.283)\end{array}$ & $\begin{array}{l}0.484^{* *} \\
(0.215)\end{array}$ & $\begin{array}{l}0.631^{* *} \\
(0.285)\end{array}$ \\
\hline Board & $\begin{array}{l}-0.005 \\
(0.017)\end{array}$ & $\begin{array}{c}0.002 \\
(0.018)\end{array}$ & $\begin{array}{c}-0.099^{* * * *} \\
(0.033)\end{array}$ & $\begin{array}{l}-0.041 \\
(0.038)\end{array}$ & $\begin{array}{c}-0.097^{* * * *} \\
(0.033)\end{array}$ & $\begin{array}{l}-0.040 \\
(0.038)\end{array}$ \\
\hline BIND & $\begin{array}{l}0.091^{* *} \\
(0.039)\end{array}$ & $\begin{array}{c}0.031 \\
(0.043)\end{array}$ & $\begin{array}{c}0.194^{* * *} \\
(0.058)\end{array}$ & $\begin{array}{c}0.038 \\
(0.079)\end{array}$ & $\begin{array}{c}0.189^{* * *} \\
(0.059)\end{array}$ & $\begin{array}{c}0.034 \\
(0.080)\end{array}$ \\
\hline CEODual & $\begin{array}{c}0.349^{*} \\
(0.188)\end{array}$ & $\begin{array}{c}-0.004 \\
(0.174)\end{array}$ & $\begin{array}{c}0.147 \\
(0.310)\end{array}$ & $\begin{array}{l}-0.407 \\
(0.510)\end{array}$ & $\begin{array}{c}0.140 \\
(0.301)\end{array}$ & $\begin{array}{c}-0.422 \\
(0.511)\end{array}$ \\
\hline Top10 & $\begin{array}{l}0.019^{* * * *} \\
(0.002)\end{array}$ & $\begin{array}{l}0.014^{* * * *} \\
(0.002)\end{array}$ & $\begin{array}{l}0.024^{* * * *} \\
(0.003)\end{array}$ & $\begin{array}{l}0.012^{* * * *} \\
(0.004)\end{array}$ & $\begin{array}{l}0.022^{* * * *} \\
(0.003)\end{array}$ & $\begin{array}{l}0.012^{* * * *} \\
(0.004)\end{array}$ \\
\hline Constant & $\begin{array}{c}29.916^{* * * *} \\
(1.115)\end{array}$ & $\begin{array}{c}27.049^{* * * *} \\
(1.043)\end{array}$ & $\begin{array}{c}31.293^{* * * *} \\
(1.771)\end{array}$ & $\begin{array}{c}29.537^{* * * *} \\
(2.019)\end{array}$ & $\begin{array}{c}31.698^{* * * *} \\
(1.783)\end{array}$ & $\begin{array}{c}29.664^{* * * *} \\
(2.028)\end{array}$ \\
\hline Year/Firm F.E & $\overline{\text { Yes }}$ & Yes & Yes & Yes & Yes & Yes \\
\hline F-Stat & 0.421 & 0.382 & 0.455 & 0.394 & 0.453 & 0.393 \\
\hline Adj. $R^{2}$ & 163.730 & 138.539 & 65.135 & 52.092 & 65.577 & 51.966 \\
\hline$N$ & 19027 & 16135 & 6577 & 5128 & 6577 & 5128 \\
\hline
\end{tabular}

Table 5 reports ordinary least square regressions examining the effect of share pledges on both current $(t)$ and future $(t)$ Tobin's Q. We interact the pledge variables with State, a binary variable equal one if the ultimate shareholder is the central or local government, or a government-controlled SOE, and zero otherwise. All other variables are as defined earlier. Two-tailed test of significance: $* * *<0.01, * *<0.05$ and $*<0.1$. 
Table 6: Pledging and size of largest shareholder

\begin{tabular}{|c|c|c|c|c|c|c|}
\hline & $\begin{array}{c}(1) \\
\text { Tobins } Q(t)\end{array}$ & $\begin{array}{c}(2) \\
\text { Tobins } Q(t+1) \\
\end{array}$ & $\begin{array}{c}(3) \\
\text { Tobins } Q(t)\end{array}$ & $\begin{array}{c}(4) \\
\text { TobinsQ }(t+1)\end{array}$ & $\begin{array}{c}(5) \\
\text { TobinsQ(t) }\end{array}$ & $\begin{array}{c}(6) \\
\text { TobinsQ }(t+1) \\
\end{array}$ \\
\hline Pledge & $\begin{array}{c}0.157 * * * \\
(0.053)\end{array}$ & $\begin{array}{c}0.206 * * * \\
(0.052)\end{array}$ & & & & \\
\hline Pledge*Large & $\begin{array}{l}-0.042 \\
(0.067)\end{array}$ & $\begin{array}{c}-0.141 * * \\
(0.067)\end{array}$ & & & & \\
\hline Pledge_Total & & & $\begin{array}{c}-0.015^{* * *} \\
(0.006)\end{array}$ & $\begin{array}{l}-0.011^{*} \\
(0.006)\end{array}$ & & \\
\hline Pledge_Total*Large & & & $\begin{array}{c}0.017 * * \\
(0.006)\end{array}$ & $\begin{array}{c}0.014 * * \\
(0.007)\end{array}$ & & \\
\hline Pledge_Largest & & & & & $\begin{array}{c}-0.004 * * * \\
(0.002)\end{array}$ & $\begin{array}{l}-0.001 \\
(0.002)\end{array}$ \\
\hline Pledge_Largest*Large & & & & & $\begin{array}{c}0.003 \\
(0.002)\end{array}$ & $\begin{array}{c}0.001 \\
(0.002)\end{array}$ \\
\hline Large & $\begin{array}{c}0.247 * * * \\
(0.057)\end{array}$ & $\begin{array}{c}0.236 * * * \\
(0.058)\end{array}$ & $\begin{array}{c}0.063 \\
(0.166)\end{array}$ & $\begin{array}{l}-0.040 \\
(0.171)\end{array}$ & $\begin{array}{c}0.150 \\
(0.168)\end{array}$ & $\begin{array}{c}0.156 \\
(0.175)\end{array}$ \\
\hline Size & $\begin{array}{c}-1.354 * * * \\
(0.056)\end{array}$ & $\begin{array}{c}-1.223^{* * *} \\
(0.052)\end{array}$ & $\begin{array}{c}-1.410^{* * *} \\
(0.087)\end{array}$ & $\begin{array}{c}-1.334^{* * *} \\
(0.098)\end{array}$ & $\begin{array}{c}-1.421 * * * \\
(0.087)\end{array}$ & $\begin{array}{c}-1.339 * * * \\
(0.098)\end{array}$ \\
\hline Growth & $\begin{array}{c}0.557 * * * \\
(0.054)\end{array}$ & $\begin{array}{c}0.293^{* * *} \\
(0.055)\end{array}$ & $\begin{array}{c}0.509 * * * \\
(0.097)\end{array}$ & $\begin{array}{c}0.406 * * * \\
(0.109)\end{array}$ & $\begin{array}{c}0.518 * * * \\
(0.097)\end{array}$ & $\begin{array}{c}0.412^{* * *} \\
(0.109)\end{array}$ \\
\hline Leverage & $\begin{array}{c}0.644 * * * \\
(0.173)\end{array}$ & $\begin{array}{c}0.844^{* * *} \\
(0.191)\end{array}$ & $\begin{array}{l}0.393^{*} \\
(0.219)\end{array}$ & $\begin{array}{c}0.599 * * \\
(0.279)\end{array}$ & $\begin{array}{l}0.416^{*} \\
(0.219)\end{array}$ & $\begin{array}{c}0.596 * * \\
(0.283)\end{array}$ \\
\hline Board & $\begin{array}{l}-0.008 \\
(0.017)\end{array}$ & $\begin{array}{c}0.002 \\
(0.018)\end{array}$ & $\begin{array}{c}-0.096 * * * \\
(0.033)\end{array}$ & $\begin{array}{l}-0.035 \\
(0.038)\end{array}$ & $\begin{array}{c}-0.097 * * * \\
(0.033)\end{array}$ & $\begin{array}{l}-0.037 \\
(0.038)\end{array}$ \\
\hline$B I N D$ & $\begin{array}{c}0.090 * * \\
(0.038)\end{array}$ & $\begin{array}{c}0.029 \\
(0.043)\end{array}$ & $\begin{array}{c}0.185 * * * \\
(0.058)\end{array}$ & $\begin{array}{c}0.035 \\
(0.080)\end{array}$ & $\begin{array}{c}0.184 * * * \\
(0.059)\end{array}$ & $\begin{array}{c}0.035 \\
(0.081)\end{array}$ \\
\hline CEODual & $\begin{array}{l}0.356^{*} \\
(0.197)\end{array}$ & $\begin{array}{l}-0.031 \\
(0.182)\end{array}$ & $\begin{array}{c}0.065 \\
(0.317)\end{array}$ & $\begin{array}{l}-0.502 \\
(0.509)\end{array}$ & $\begin{array}{c}0.090 \\
(0.314)\end{array}$ & $\begin{array}{l}-0.489 \\
(0.509)\end{array}$ \\
\hline Top2to10 & $\begin{array}{c}0.014 * * * \\
(0.002)\end{array}$ & $\begin{array}{c}0.008^{* * *} \\
(0.002)\end{array}$ & $\begin{array}{c}0.014 * * * \\
(0.003)\end{array}$ & $\begin{array}{c}0.003 \\
(0.004)\end{array}$ & $\begin{array}{c}0.014 * * * \\
(0.003)\end{array}$ & $\begin{array}{c}0.003 \\
(0.004)\end{array}$ \\
\hline Constant & $\begin{array}{c}29.533 * * * \\
(1.133)\end{array}$ & $\begin{array}{c}26.650 * * * \\
(1.059)\end{array}$ & $\begin{array}{c}31.194 * * * \\
(1.792)\end{array}$ & $\begin{array}{c}29.495 * * * \\
(2.005)\end{array}$ & $\begin{array}{c}31.446 * * * \\
(1.816)\end{array}$ & $\begin{array}{c}29.470 * * * \\
(2.023)\end{array}$ \\
\hline Year/Firm F.E & Yes & Yes & Yes & Yes & Yes & Yes \\
\hline F-Stat & 162.316 & 139.874 & 63.796 & 52.414 & 64.626 & 52.067 \\
\hline Adj. $R^{2}$ & 0.415 & 0.378 & 0.446 & 0.393 & 0.446 & 0.392 \\
\hline$N$ & 19027 & 16135 & 6577 & 5128 & 6577 & 5128 \\
\hline
\end{tabular}

Table 6 reports ordinary least square regressions examining the effect of share pledges on both current $(t)$ and future $(t)$ Tobin's Q. We interact the pledge variables with Large, a binary variable equal to one if the largest shareholder's ownership interests in the firm is greater than the median ownership interests amongst the largest shareholders of all sample firms, and zero otherwise. We also replace Top10 with Top2to10, which captures the combined ownership interests of the top ten shareholders, excluding the shares owned by the largest shareholder. All other variables are as defined earlier. Two-tailed test of significance: $* * *<0.01, * *<0.05$ and $*<0.1$. 
Table 7: Changes in pledge status

\begin{tabular}{|c|c|c|c|c|}
\hline & $\begin{array}{c}(1) \\
\text { TobinsQ(t) }\end{array}$ & $\begin{array}{c}(2) \\
\text { TobinsQ }(t+1)\end{array}$ & $\begin{array}{c}(3) \\
\text { TobinsQ(t) }\end{array}$ & $\begin{array}{c}(4) \\
\text { TobinsQ(t+1) }\end{array}$ \\
\hline StopPledge & $\begin{array}{l}-0.056 \\
(0.083)\end{array}$ & $\begin{array}{l}-0.179^{* *} \\
(0.077)\end{array}$ & & \\
\hline StartPledge & & & $\begin{array}{c}0.150^{* * *} \\
(0.055)\end{array}$ & $\begin{array}{c}0.102 \\
(0.065)\end{array}$ \\
\hline Size & $\begin{array}{c}-1.513^{* * *} \\
(0.103)\end{array}$ & $\begin{array}{c}-1.488^{* * *} \\
(0.125)\end{array}$ & $\begin{array}{c}-1.400^{* * * *} \\
(0.074)\end{array}$ & $\begin{array}{c}-1.148^{* * *} \\
(0.062)\end{array}$ \\
\hline Growth & $\begin{array}{c}0.460^{* * *} \\
(0.106)\end{array}$ & $\begin{array}{c}0.340^{* * *} \\
(0.118)\end{array}$ & $\begin{array}{c}0.491^{* * *} \\
(0.070)\end{array}$ & $\begin{array}{c}0.266^{* * *} \\
(0.065)\end{array}$ \\
\hline Leverage & $\begin{array}{c}0.481^{*} \\
(0.256)\end{array}$ & $\begin{array}{l}0.879^{* *} \\
(0.390)\end{array}$ & $\begin{array}{c}0.773^{* * *} \\
(0.257)\end{array}$ & $\begin{array}{c}0.738^{* * *} \\
(0.245)\end{array}$ \\
\hline Board & $\begin{array}{l}-0.097^{* *} \\
(0.038)\end{array}$ & $\begin{array}{l}-0.063 \\
(0.040)\end{array}$ & $\begin{array}{c}0.016 \\
(0.022)\end{array}$ & $\begin{array}{c}0.024 \\
(0.023)\end{array}$ \\
\hline BIND & $\begin{array}{c}0.221^{* * *} \\
(0.066)\end{array}$ & $\begin{array}{c}0.129 \\
(0.081)\end{array}$ & $\begin{array}{c}0.049 \\
(0.058)\end{array}$ & $\begin{array}{l}-0.013 \\
(0.060)\end{array}$ \\
\hline CEODual & $\begin{array}{c}0.017 \\
(0.346)\end{array}$ & $\begin{array}{l}-0.428 \\
(0.551)\end{array}$ & $\begin{array}{l}0.558^{* *} \\
(0.251)\end{array}$ & $\begin{array}{c}0.230 \\
(0.177)\end{array}$ \\
\hline Top10 & $\begin{array}{c}0.025^{* * *} \\
(0.004)\end{array}$ & $\begin{array}{c}0.013^{* * *} \\
(0.004)\end{array}$ & $\begin{array}{c}0.022^{* * *} \\
(0.003)\end{array}$ & $\begin{array}{c}0.015^{* * *} \\
(0.003)\end{array}$ \\
\hline Constant & $\begin{array}{c}31.852^{* * *} \\
(2.047)\end{array}$ & $\begin{array}{c}31.703^{* * *} \\
(2.504)\end{array}$ & $\begin{array}{c}29.331^{* * *} \\
(1.453)\end{array}$ & $\begin{array}{c}24.410^{* * *} \\
(1.212)\end{array}$ \\
\hline Year/Firm F.E & Yes & Yes & Yes & Yes \\
\hline F-Stat & 61.202 & 48.578 & 111.799 & 99.568 \\
\hline Adj. $R^{2}$ & 0.441 & 0.401 & 0.42 & 0.363 \\
\hline$N$ & 5108 & 3992 & 10949 & 9522 \\
\hline
\end{tabular}

Table 7 reports ordinary least square regressions examining the effect ceasing or commencing share pledges on both current $(t)$ and future $(t)$ Tobin's Q. Columns (1) and (2) are run on that had a shareholder pledge in the previous year, whilst Columns (3) and (4) are run on firms that did not have a shareholder pledge in the previous year. The variables of interests are StopPledge, an indicator variable that equals one when firms cease having shareholder pledges and zero otherwise and StartPledge, an indicator variable that equals one when firms commence having shareholder pledges and zero otherwise. All other variables are as defined earlier. Two-tailed test of significance: $* * *<0.01, * *<0.05$ and $*<0.1$. 